\title{
PHENOTYPIC AND GENOTYPIC CHARACTERISATION OF CLINICAL ISOLATES OF NOSOCOMIAL INFECTIONS
}

\author{
Korotetskiy I. S. ${ }^{1}$, Jumagaziyeva A. B. ${ }^{1}$, Shilov S. V. ${ }^{1}$, Kuznetsova T. V. ${ }^{1}$, \\ Iskakbayeva Z. A. ${ }^{1}$, Myrzabayeva A. N. ${ }^{1}$, Korotetskaya N.V. ${ }^{1}$, Ilin A. I. ${ }^{1}$, Reva $O$. \\ $\mathrm{N}^{2}$ \\ ${ }^{1}$ Scientific Center for Anti-Infectious Drugs, \\ 75A al-Farabi Ave., Almaty, 050060, Kazakhstan \\ ${ }^{2}$ Centre for Bioinformatics and Computational Biology; Department of Biochemistry, \\ Genetics and Microbiology; University of Pretoria, Pretoria, South Africa \\ laeda1@mail.ru
}

\section{ABSTRACT}

The study focuses on identification and characterization of clinical isolates of nosocomial infections with an aim to create a Bank of model microorganisms for further study of mechanisms and prospects of clinical use of novel medicines causing a reversion susceptibility to antibiotics in drug resistant pathogens.

Clinical samples of nosocomial infections were collected from phthisiological hospitals in Almaty. Clinical isolates were characterized by morpho-cultural, tinctorial, physiological and biochemical properties and also by susceptibility to antibiotics. Our studies showed that the isolates are characterized by an increased ability to form biofilms that significantly complicates the therapy and prevention of these outbreaks. Moreover, isolates were characterized by varying degrees of susceptibility to antimicrobial drugs. The strains of Citrobacter were resistant to azithromycin, which is considered as a reserve drug. This fact raises a concern about the circulation and the spread in hospitals of microorganisms resistant to the latest generation of antibiotics.

Obtained genome-scale contigs were used for taxonomic affiliation of the isolates and for identification of genetic determinants of antibiotic resistance. The search for genetic determinants of drug resistance in the obtained genome sequences confirmed the resistance to some antibiotics obtained by phenotypic methods.

Whole genome sequences were obtained for 4 clinical isolates identified as Citrobacter koseri SCAID URN1-2019, Citrobacter freundii SCAID PHRX1-2019, Escherichia coli SCAID URN1-2019 and Streptococcus pneumoniae SCAID PHRX1-2019. The genomes were deposited in the NCBI database under accession numbers CP052059, CP052058, CP052057, and CP052060.

Key words: nosocomial infection, pathogen, DNA, sequencing, Citrobacter koseri, Citrobacter freundii, Escherichia coli, Streptococcus pneumoniae.

\section{INTRODUCTION}

Hospital-acquired infections (HAI), also known as a nosocomial infection, are among the most important problems of modern medicine and health care in all countries of the world, causing huge socio-economic damage, increasing hospital mortality, disease complications, and increase of duration of the stay in hospitals. Among HAI, 
especially dangerous are infections of newborns followed by postoperative infections [1-3].

Distribution of HAI is affected by disobeying of sanitary norms and regulations in the hospitals, overcrowding of patients and hospital staff members, non-compliance with hygiene rules by the medical personnel, untimely disinfection of medical equipment, and some other factors. A significant increase in emergence of antibioticresistant HAI, which are resistant to antibiotics of the latest generation has complicated dramatically the problem with nosocomial infections [4,5].

Nosocomial infections occur in $7-10 \%$ of all hospitalized patients [6]. The most common complications are incidences of pneumonia associated with artificial ventilation (15-25\%), septicemia and urinary tract infections associated with the use of urinary catheter (28-40\%), and postoperative infections (24-36 \%) [7-9].

Approximately $90 \%$ of all the hospital-acquired infections are of bacterial origin. Taxonomic variety of pathogens may differ in different groups of patient, medical institutions and hospital associated environments. The most commonly nosocomial pathogens are Staphylococcus aureus, Pseudomonas aeruginosa, Enterococcus spp., Escherichia coli, Klebsiella spp., Enterobacter spp., Acinetobacter spp. [10].

Because of frequent cases of antibiotic resistance among HAI, it is getting increasingly difficult to treat nosocomial infections. Disease outbreak may develop within 48-72 hours after a patient got infected with a nosocomial pathogen, which often shows an increased drug resistance. Based on the data provided by WHO, antibiotic resistance is observed most frequently in Escherichia coli, Klebsiella pneumonia, Staphylococcus aureus, Streptococcus pneumoniae [11]. The main threats to the Global health system are Pseudomonas aeruginosa together with Enterobacteriaceae resistant to vancomycin and carbapenems [12], as well as Staphylococcus resistant to methicillin [13].

Constant monitoring of HAI pathogens is one of the most important approach to control and prevent these infections. There is a need to improve laboratory diagnostics, in particular the methods for detection of susceptibility of hospital isolates of microorganisms to antibacterial drugs and various disinfectants. Genomic analysis of individual organisms, population dynamics, and microbial community ecology studies make it easier to identify new pathogens, track disease outbreaks, and study evolution of antibiotic resistance.

\section{Materials and methods}

Isolation of clinical isolates was carried out by sampling biological material with a sterile swab or by direct seeding of biological fluids on differential diagnostic media with subsequent identification by bacteriological methods. A total 5 strains were isolated. Isolates were storage on slant agar at $4 \pm 2{ }^{\circ} \mathrm{C}$ during the identification. Cryoconservation of isolates was performed by storage in liquid protective medium at $80^{\circ} \mathrm{C}$ after complete identification. Primary identification of clinical isolates, preparation of pure cultures, morpho-cultural, tinctorial, physiological and biochemical trials were carried out following the «Manual for the Laboratory Identification and Antimicrobial Susceptibility Testing of Bacterial Pathogens of Public Health Importance in the Developing World» (WHO/CDS/CSR/RMD/2003.6), M35-A2 Abbreviation Identification of Bacteria and Yeasts Approved Guideline-Second Edition [14, 15], CLSI and Bergey's Manual of Systematic Bacteriology [16]. The tinctorial properties of clinical isolates were studied by Gram-staining of smears using a standard commercial kit followed by light microscopy and recording other taxon-specific cell morphology parameters. For typing isolates used well-standardized commercial test system STREPTOtest 16, STAPHYtest 16, EN-COCCUStest and NEFERMtest 24 [17]. 
Antibiotic sensitivity profiling of clinical isolates was performed by the disc diffusion method [18]. Determination of the biofilm-forming ability of the isolates was carried out as described before [19].

DNA samples were extracted from bacterial cells using PureLink Genomic DNA Kits (Publication Number: MAN0000601, Revision 2.0) following the manufacturer's recommendations. The quality and quantity of the resulting DNA samples were determined using the NanoDrop 2000c spectrophotometer (Thermo Scientific, USA) at optical wavelengths of 260 and $280 \mathrm{~nm}$.

The Ion Torrent PGM sequencer (USA) was used to sequence genomic DNA samples. The DNA library for prepared for sequencing by an enzymatic approach using the Ion Xpress Plus Fragment Library Kit (Life Technologies, USA). The degree and quality of fragmentation of the DNA library were evaluated by Bioanalyzer 2100 (Agilent). DNA reads barcoding for multiplex sequencing was carried out using the Xpress Barcode Adapters Kit (Life Technologies, USA). Sequencing of the resulting library was carried out on the Ion 318 Chip using Ion PGM Hi-Q View Sequencing Kit. At each of the intermediate stages, the quality and quantity of the DNA library were monitored. All operations were carried out according to the manufacturer's instructions.

The quality control and trimming of DNA reads were carried out using the computer programs fastqcand Cassava fastq filter. De novo assembly was performed by the SPAdes V 3.1.0 assembler [20]. Large genome contigs were used to search for the closest reference genomes in the NCBI database. Genome consensus sequences were obtained by mapping DNA reads against the respective reference genomes using the program Bowtie implemented in UGENE v. 34.0 [21]. DNA contigs assembled de novo by SPAdes were aligned against the genome consensus sequences using the program Mauve 20150226 [22]. Identified strain specific genomic regions were incorporated into the genome sequence using an in-house script written on Python 2.7, which replaces the referential sequence loci with homologous fragments of contigs. Automatic search for coding genes was carried by NCBI annotation pipeline. The complete genome sequences obtained in this study were deposited at NCBI under accession numbers CP052059, CP052058, CP052057, and CP052060.

Prediction of possible genetic determinants involved in antibiotic resistance in the complete genome sequences obtained on the previous step was performed by using the Web portal RGI 5.1.0, CARD 3.0.8 [23]. Strict significance option of gene filtering based on CARD curated bitscore cut-offs were used. Other parameters of identification of antibiotic resistance genes in complete bacterial genomes were set by default.

\section{RESULTS}

During the year 2019, clinical samples of nosocomial infections were collected from phthisiological hospitals in Almaty.

Phenotypic characterization of the isolates was performed using the same approaches and diagnostic systems, which are used routinely in hospitals for identification of pathogens. Isolates shown in table 1, which represent different etiological types of hospital-acquired infections (HAI), were selected for further study.

Table 1. Clinical isolate and its source of isolation

\begin{tabular}{|l|l|}
\hline \multicolumn{1}{|c|}{ Isolate } & Source selection \\
\hline Citrobacter koseri $^{*}$ SCAID URN1-2019 & Urine \\
\hline Citrobacter freundii SCAID PHRX1-2019 & The mucosa of the oropharynx \\
\hline Escherichia coli SCAID URN1-2019 & Urine \\
\hline Streptococcus pneumoniae SCAID PHRX1-2019 & The mucosa of the oropharynx \\
\hline Pseudomonas aeruginosa spp. SCAID PHRX1- & The mucosa of the oropharynx \\
\hline
\end{tabular}


Note. *Species belonging of these isolates was identified by phenotype and genotype as it will be explained in the following sections of the paper.

All studied isolates were identified to the genus and species level using phenotypic descriptors and genetic markers as it will be explained below. They were deposited at the unique accession numbers assigned according to international standards and specifications of collecting virulent clinical isolates $[15,16,17]$ in the JSC Scientific Centre for Anti-infectious Drugs (SCAID) culture collection were .

On the differential diagnostic medium Endo Agar (Himedia), Citrobacter were characterized by forming of beige color rounded, slimy and shiny colonies with uneven edges up to $3 \mathrm{~mm}$ in diameter. On deoxycholate citrate agar (Himedia), Citrobacter colonies produced pink colored colonies. Growth of Citrobacter on deoxycholate citrate agar with xylose and lysine changes the medium color from red to orange. Fermentation of sucrose, lactose, diamond green and phenolic red recorder by medium color change also is characteristic for Citrobacter.

Bacteria of the genus Escherichia primary were selected by forming round translucent colonies with a diameter of 3-5 $\mathrm{mm}$ on meat-peptone agar. On the Endo medium, these cultures formed small colonies with a metallic, which are typical for lactose-positive representatives of the Enterobacteriaceae family.

The clinical isolate of St. pneumoniae SCAID PHRX1-2019 were examined on blood agar where they form small white round colonies with smooth edges, $0.5-1 \mathrm{~mm}$ in diameter, convex profile, and soft consistency.

For differentiation of bacteria of the genus Pseudomonas, cetrimide agar was used. On this medium, the bacteria of this genus form round flat smooth edge translucent and shiny colonies of soft consistency with a characteristic diffusion of the pyocin pigment into the medium.

Tables 2-3 summarize morphological and biochemical properties of the selected isolates.

Table 2. Physiological and biochemical characteristics of clinical isolates of the Enterobacteriaceae family

\begin{tabular}{|c|c|c|c|}
\hline \multirow[t]{3}{*}{ Name of test } & \multicolumn{3}{|c|}{ Isolates } \\
\hline & $\begin{array}{l}\text { Citrobacter } \\
\text { freundii SCAID } \\
\text { PHRX1-2019 }\end{array}$ & $\begin{array}{l}\text { Citrobacter koseri } \\
\text { SCAID URN1- } \\
2019\end{array}$ & $\begin{array}{l}\text { Escherichia coli } \\
\text { SCAID URN1- } \\
2019\end{array}$ \\
\hline & \multicolumn{3}{|c|}{ Reaction } \\
\hline Hemolysis & - & + & - \\
\hline Indole & - & + & + \\
\hline Urease & - & - & - \\
\hline Arginine & - & + & + \\
\hline Ornithine & - & + & - \\
\hline Lysine & - & - & + \\
\hline Hydrogen sulphide & + & - & - \\
\hline Simmons Citrate & + & + & - \\
\hline Malonate & - & + & - \\
\hline$\beta$ galactosidase & + & + & + \\
\hline Salicin & - & - & - \\
\hline Sorbitol & + & + & + \\
\hline Melibiose & + & - & + \\
\hline Cellobiose & - & + & - \\
\hline Lactose & + & - & + \\
\hline
\end{tabular}




\begin{tabular}{|l|c|c|c|}
\hline Trehalose & + & + & + \\
\hline Mannitol & + & + & + \\
\hline$\beta$-glucuronidase & - & - & - \\
\hline Dulcet & + & - & - \\
\hline Adonitol & - & + & - \\
\hline Arabitol & - & + & - \\
\hline Sucrose & + & + & - \\
\hline Inositol & + & + & - \\
\hline Raffinose & + & - & - \\
\hline Esculin & - & - & - \\
\hline ß xyloside & - & - & \\
\hline \multicolumn{2}{|l|}{ Note: «+» positive test result, «-» negative test result } \\
\hline
\end{tabular}

The results of the research showed that the clinical isolate of Citrobacter freundii SCAID PHRX1-2019 isolated from the oropharynx was characterized by formation of hydrogen sulfide and ability to utilize citrate as a sole source of carbon and energy. The high fermentation activity of different sugars was also observed. The isolated strain does not produce indole and shows a negative reaction on malonate fermentation and ornithine decarboxylation.

Citrobacter koseri SCAID URN1-2019 produces indole and showsfermentation of several carbohydrates with acid production: sorbitol, cellobiose, trehalose, mannitol, adonitol, arabitol, sucrose and inositol. It can dehydratase arginine and decarboxylase ornithine by enzymes, which are involved in the cleavage of amino acids. The strain shows also a $\beta$-galactosidase activity that is involved in hydrolysis of glycosidic bonds.

Escherichia coli SCAID URN1-2019 produces indole, ferments many carbohydrates including sorbitol, melibiose, lactose, trehalose and mannitol. It produces $\beta$-galactosidase involved in hydrolysis of glycosidic bonds and lactose disaccharide, and catalyzes arginine dehydrolase by an enzymes lysine decarboxylase involved in the decarboxylation of amino acids.

Table 3. Physiological and biochemical signs of Streptococcus pneumoniae clinical isolate SCAID PHRX1-2019

\begin{tabular}{|l|c|}
\hline Name of test & Reaction \\
\hline Hemolysis & $\alpha$-hemolysis \\
\hline Hippurate & + \\
\hline Phosphatase & + \\
\hline Leucine aminopeptidase & - \\
\hline$\beta$-glucuronidase & + \\
\hline$\alpha$-galactosidase & + \\
\hline Voges-Proskauer test & - \\
\hline Pyrrolidonyl Arylamidase & - \\
\hline Esculin & - \\
\hline Arginine & - \\
\hline Urease & - \\
\hline Mannitol & - \\
\hline Sorbitol & - \\
\hline Trehalose & + \\
\hline Lactose & + \\
\hline Raffinose & - \\
\hline Inulin & + \\
\hline Melibiose & - \\
\hline Ribose & - \\
\hline
\end{tabular}


Note: «+» positive test result, «-» negative test result

The clinical isolate Streptococcus pneumoniae SCAID PHRX1-2019 was characterized by $\alpha$-hemolysis, positive Voges-Proskauer test with the formation of acetoin, and by formation of hippurate hydrolyze. Other enzymatic activities of this strain include was production of phosphatase that detaches phosphate groups from organic molecules; leucine aminopeptidase responsible for the hydrolysis of leucine; and $\alpha$-galactosidase involved in cleavage of galacto-oligosaccharides. The strain shows also a saccharolytic activity and fermentation of lactose, raffinose and melibiose. Biochemical activities of the strain Pseudomonas aeruginosa SCAID PHRX1-2019 are summarized in Table 4.

Similar experiments to evaluate the biochemical characteristics were performed for an isolate belonging to the genus Pseudomonas (table 4).

Table 4. Physiological and biochemical features of Pseudomonas aeruginosa isolate.

\begin{tabular}{|l|c|l|c|}
\hline \multicolumn{1}{|c|}{ Name of test } & Reaction & \multicolumn{1}{|c|}{$\begin{array}{c}\text { Fermentation of } \\
\text { carbohydrates }\end{array}$} & Reaction \\
\hline Growth at $42{ }^{0} \mathrm{C}$ & + & Maltose & - \\
\hline Pyocyanin production & + & Mannitol & - \\
\hline Oxidase test & + & Sucrose & - \\
\hline Catalase test & + & Lactose & - \\
\hline Lysine decarboxylase & - & Galactose & - \\
\hline Arginine dihydrolase & + & Xylose & - \\
\hline Ornithine decarboxylase & - & acetamide & + \\
\hline Gelatin hydrolysis test & + & arabinose & - \\
\hline$\beta$-glucosidase & - & Inosine & + \\
\hline$\alpha$-galactosidase & - & Simmons citrate & + \\
\hline \multicolumn{2}{|l}{} & Malonate & - \\
\cline { 2 - 4 } & & Esculin & + \\
\cline { 2 - 4 } & Urease & \\
\hline Note: «+» positive test result, «-» negative test result & \multicolumn{2}{l}{} \\
\hline
\end{tabular}

Clinical isolate Pseudomonas aeruginosa SCAID PHRX1-2019 can grow at $42{ }^{\circ} \mathrm{C}$, it is oxidase- and catalase-positive, decarboxylates arginine. It shows a strong proteolytic activity, which is one of the important factors of invasion and decomposition of tissue barrier cells and intercellular substances. Other activities include blood serum coagulation, casein hydrolysis, and hemoglobin decomposition. A characteristic feature of the strain was mucus formation. The isolate showed a low saccharolytic activity and the ability to use citrate as a sole source of carbon.

$P$. aeruginosa produces characteristic blue-green fluorescent pigments, which included pyocyanin and pyoverdine (yellow-green fluorescent pigment). These pigments are characteristic for $P$. aeruginos $a$ and serve as their pathogenicity factors.

Ability of the isolated strains to form biofilms was investigated. It was found that the enforced antibiotic resistance of microorganisms in biofilms compared to planktonic forms is due to the ability of bacteria to accumulate extracellular enzymes in the matrix that destroy antibiotics. The biofilm matrix can reduce accessibility of antibiotics to bacterial cells. The reduced metabolism of microorganisms in lower layers of the biofilm also contributes to the resistance phenotype. It is generally recognized that the ability to form biofilms is a pathogenicity and drug resistance factor of nosocomial infections. In this study it was found that all the clinical isolates had a significant biofilm-forming ability. Biofilm formation indices of Citrobacter koseri SCAID URN1- 
2019, Citrobacter freundii SCAID PHRX1-2019 and E. coli SCAID URN1-2019 were 2.7, 2.4 and 2.9, respectively, which are considered as a strong biofilm formation.

The biofilm formation index calculated for $P$. aeruginosa spp. SCAID PHRX12019 was 5.2 that is also regarded as an active biofilm formation.

The lowest ability to form biofilms, 1.3, was reported for Streptococcus pneumoniae SCAID PHRX1-2019 isolated from oropharynx.

On the next step of the study, antibiotic susceptibility of the isolates was detected by using the disco-diffusion method against 18 the most common antibiotics used in antibacterial therapy. The results of this study are summarized in Table 5.

Analysis of the obtained data showed that the clinical isolates were characterized by varying degrees of sensitivity to antimicrobial drugs.

Citrobacter freundii SCAID PHRX1-2019 and Citrobacter koseri SCAID URN1, which were isolated from oropharynx and urine truct respectively, showed resistance to oxacillin, azithromycin, erythromycin, streptomycin, and clindamycin. Additionally, Citrobacter freundii SCAID PHRX1-2019 was resistant to carbenicillin and ampicillin, and showed an intermediate sensitivity to amoxicillin, gentamicin, ceftriaxone, ciprofloxacin and cefepim.

E. coli SCAID URN1-2019 showed resistance to $\square$-lactam antibiotics oxacillin, amoxicillin and ampicillin; macrolide antibiotic erythromycin and semisynthetic antibiotic clindamycin of the lincosamide group.

Streptococcus pneumonia SCAID PHRX1-2019 was resistant to amikacin, cefepim, cefamandol, streptomycin and oxacillin, and showed an intermediate sensitivity to azithromycin, ceftriaxone, carbenicillin and ampicillin.

$P$. aeruginosa spp. SCAID PHRX1-2019 isolated from oropharynx was resistant to $\beta$-lactam antibiotics oxacillin, amoxicillin, carbenicillin and ampicillin; cephalosporins cefazoline and cefepim; macrolide antibiotic erythromycin; and lincosamide antibiotic clindamycin. 
Table 5. Sensitivity of clinical isolates to antibacterial drugs

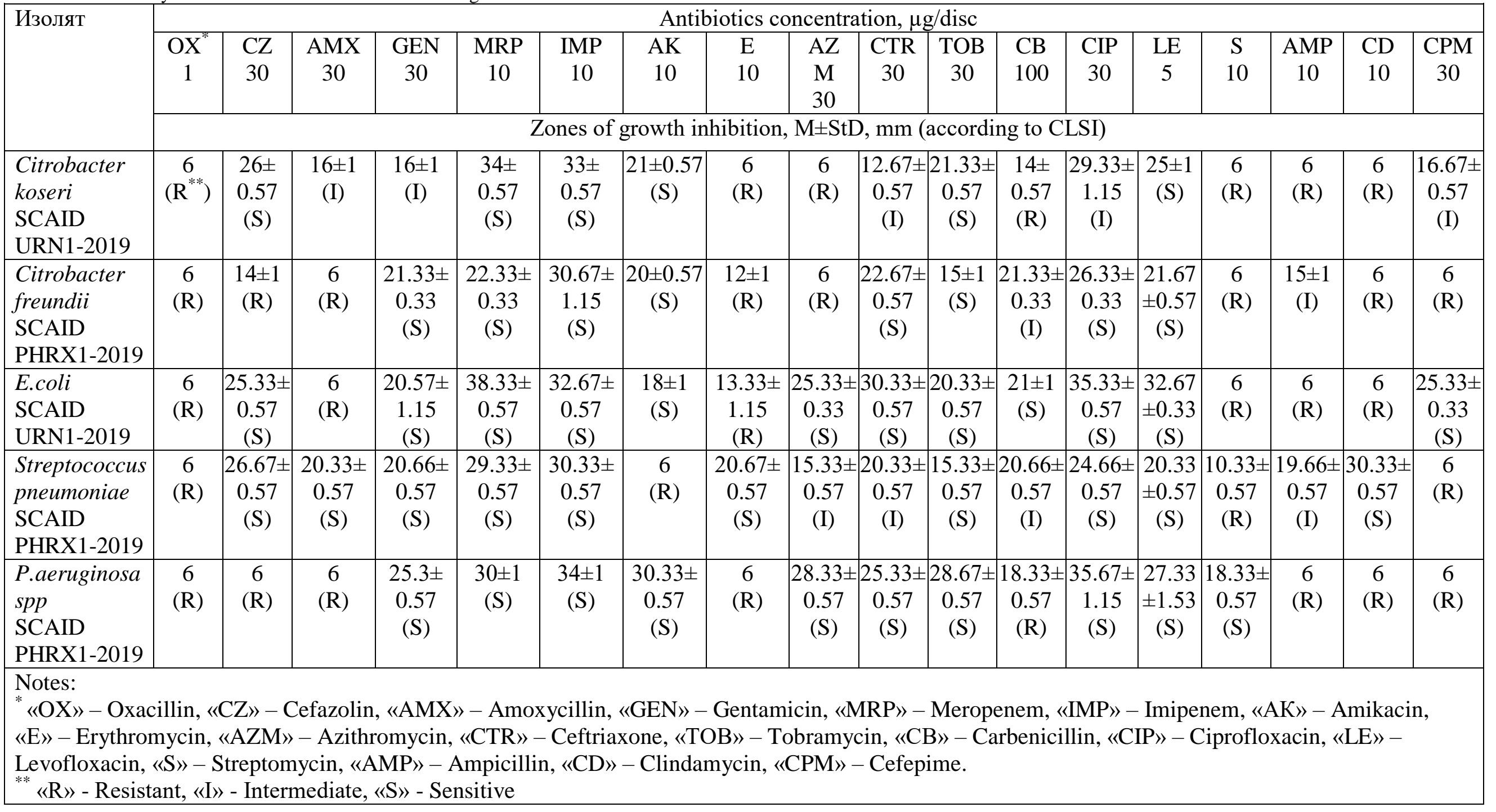


The four above-mentioned isolates were selected for subsequent whole genome sequencing performed on the IonTorrent PGM platform as the most interesting isolates for further study of mechanisms and prospects of clinical use of novel medicines causing a reversion susceptibility to antibiotics in drug resistant pathogens.

The largest contigs were used to search for homologous sequences through the NCBI $n r$ database. Closely related genomes were used read mapping using the Bowtie program implemented in the UGENE V. 34.0 followed by consensus sequence generation by the UGENE internal algorithm. Respectively, the reference genome of Streptococcus pneumoniae strain CP2215 (access number CP028436.1) was used as a references for assembly of DNA reads generated from genomic DNA of Streptococcus pneumoniae SCAID PHRX1-2019; Escherichia coli strain 9 (access number CP048304.1) was used as a reference for the Escherichia coli SCAID URN1-2019; Citrobacter koseri strain ATCC VAA-895 (access number CP000822.1) for Citrobacter koseri SCAID URN1-2019; and Citrobacter freundii strain 680 (access number CP038658. 1) for Citrobacter freundii SCAID PHRX1-2019. Consensus nucleotide sequences were obtained for all read mappings. Contigs created from DNA reads by the program SPAdes were aligned against the genomic consensus sequences to identify and incorporate the strain-specific regions located in the mid parts of the contigs, which were properly aligned against the consensus sequences. Gene prediction was performed by the NCBI annotation robot. The resulting genome sequences were deposited in the NCBI under accession numbers shown in table 6.

Table 6. Whole genome sequences of SCAID virulent clinical isolates deposited at NCBI

\begin{tabular}{|l|l|l|l|}
\hline Isolate & GenBankAC & $\begin{array}{l}\text { Length } \\
\text { including gaps }\end{array}$ & $\begin{array}{l}\text { GC- } \\
\text { content }\end{array}$ \\
\hline Streptococcus_SCAID_PHRX1-2019 & CP052060 & 1963680 & 39.89 \\
\hline Escherichia_coli_SCAID_URN1-2019 & CP052057 & 4937450 & 50.70 \\
\hline Citrobacter koseri SCAID URN1-2019 & CP052059 & 4650688 & 53.88 \\
\hline Citrobacter freundii SCAID PHRX1-2019 & CP052058 & 4664379 & 51.93 \\
\hline
\end{tabular}

All these sequences were deposited at NCBI under the BioProject PRJNA627194.

RGI online service (https://card.mcmaster.ca/analyze/rgi) was used to predict genome specific resistomes based on the obtained genome sequences of selected clinical isolates using the NCBI accession numbers as input data. The results of the analysis are presented in table 7.

Table 7. Identification of drug resistance determinants in whole genome sequences by CARD RDI

\begin{tabular}{|c|c|c|c|}
\hline Genome & $\begin{array}{l}\text { Resistance } \\
\text { Mechanism }\end{array}$ & $\begin{array}{l}\text { Gene } \\
\text { number }\end{array}$ & Drug Class \\
\hline \multirow{2}{*}{$\begin{array}{l}\text { Streptococcus } \\
\text { pneumoniae SCAID } \\
\text { PHRX1-2019 }\end{array}$} & antibiotic efflux & 2 & Quinolones \\
\hline & $\begin{array}{l}\text { antibiotic target } \\
\text { alteration }\end{array}$ & 1 & Macrolides, lincosamides \\
\hline $\begin{array}{l}\text { Escherichia coli SCAID } \\
\text { URN1-2019 }\end{array}$ & antibiotic efflux & 35 & $\begin{array}{l}\text { Aminoglycosides, } \\
\text { quinolones, } \\
\text { cephalosporins, } \beta \text { - } \\
\text { lactams; tetracyclines; } \\
\text { rifamycin; } \\
\text { chloramphenicol, } \\
\text { triclosan, } \\
\text { aminocoumarins, } \\
\text { macrolides, }\end{array}$ \\
\hline
\end{tabular}




\begin{tabular}{|c|c|c|c|}
\hline & & & $\begin{array}{l}\text { benzalkonium chloride; } \\
\text { rhodamine, peptide } \\
\text { antibiotic, } \\
\text { fosfomycin, } \\
\text { nitroimidazole. }\end{array}$ \\
\hline & $\begin{array}{l}\text { antibiotic } \\
\text { inactivation }\end{array}$ & 2 & $\beta$-lactams \\
\hline & $\begin{array}{l}\text { antibiotic target } \\
\text { alteration }\end{array}$ & 6 & $\begin{array}{l}\text { Peptide antibiotic, } \\
\text { elfamycin, sulfonamide, } \\
\text { quinolones, } \\
\text { glycylcycline; penam; } \beta \text { - } \\
\text { lactams, tetracyclines, } \\
\text { rifamycin, phenicols. }\end{array}$ \\
\hline & $\begin{array}{l}\text { reduced } \\
\text { permeability to } \\
\text { antibiotic }\end{array}$ & 1 & $\begin{array}{l}\text { Quinolones, } \quad \beta \text {-lactams, } \\
\text { tetracyclines; rifamycin; } \\
\text { phenicol; triclosan. }\end{array}$ \\
\hline \multirow[t]{4}{*}{$\begin{array}{l}\text { Citrobacter koseri } \\
\text { SCAID URN1-2019 }\end{array}$} & antibiotic efflux & 16 & $\begin{array}{l}\text { Quinolones, } \\
\text { tetracyclines, } \\
\text { aminoglycosides, } \\
\text { aminocoumarins, } \\
\text { macrolides, } \beta \text {-lactams, } \\
\text { tetracyclines, rifamycin, } \\
\text { phenicol, triclosan, } \\
\text { benzalkonium chloride, } \\
\text { rhodamine, peptide } \\
\text { antibiotic; fosfomycin, } \\
\text { nitroimidazole. }\end{array}$ \\
\hline & $\begin{array}{l}\text { antibiotic } \\
\text { inactivation }\end{array}$ & 3 & $\beta$-lactams \\
\hline & $\begin{array}{l}\text { antibiotic target } \\
\text { alteration }\end{array}$ & 9 & $\begin{array}{l}\text { Elfamycin, fosfomycin, } \\
\beta \text {-lactams, sulfonamides, } \\
\text { quinolones, tetracyclines, } \\
\text { rifamycin, phenicol, } \\
\text { triclosan. }\end{array}$ \\
\hline & $\begin{array}{l}\text { reduced } \\
\text { permeability to } \\
\text { antibiotic }\end{array}$ & 2 & Quinolones, $\beta$-lactams \\
\hline \multirow[t]{3}{*}{$\begin{array}{l}\text { Citrobacter freundii } \\
\text { SCAID PHRX1-2019 }\end{array}$} & antibiotic efflux & 18 & $\begin{array}{l}\text { Aminoglycosides, } \\
\text { aminocoumarins, } \\
\text { quinolones, } \beta \text {-lactams, } \\
\text { tetracyclines, rifamycin, } \\
\text { phenicol, triclosan, } \\
\text { fosfomycin, macrolides, } \\
\text { peptide antibiotic, } \\
\text { nitroimidazole, } \\
\text { benzalkonium chloride; } \\
\text { rhodamine. }\end{array}$ \\
\hline & $\begin{array}{l}\text { antibiotic } \\
\text { inactivation }\end{array}$ & 2 & $\beta$-lactams \\
\hline & $\begin{array}{l}\text { antibiotic target } \\
\text { alteration }\end{array}$ & 8 & $\begin{array}{lr}\beta \text {-lactams, } & \text { elfamycin, } \\
\text { fosfomycin, } & \text { peptide }\end{array}$ \\
\hline
\end{tabular}




\begin{tabular}{|l|l|l|l|}
\hline & & $\begin{array}{l}\text { antibiotic, sulfonamide } \\
\text { antibiotic, quinolones, } \\
\text { tetracyclines, rifamycin, } \\
\text { phenicol, triclosan. }\end{array}$ \\
\cline { 2 - 4 } & $\begin{array}{l}\text { antibiotic target } \\
\text { protection }\end{array}$ & 1 & Quinolones \\
\hline
\end{tabular}

Our study shows that the sequenced genomes differed by several genes encoding antibiotic target alteration, which probably were acquired by horizontal gene transfer. Genetic profiling of drug resistance determinants in whole-genome sequences by CARD RDI confirmed antibiotic resistance predicted by phenotypic methods. In addition, the RGI online service made it possible to predict resistance to a number of antibiotics, resistance to which was not shown by the disco-diffusion method. The discrepancy between predicted and actual antibiotic resistance may be due to the silence of the genes responsible for resistance.

\section{DISCUSSION}

As part of our study of mechanisms and prospects of clinical use of novel medicines causing a reversion susceptibility to antibiotics in drug resistant pathogens, we are working to identify and characterize clinical isolates of nosocomial infections [24]. Clinical samples of nosocomial infections were collected from phthisiological hospitals in Almaty. As a result, 5 isolates of pathogens associated with nosocomial infections were identified. Standard approaches of identification of pathogens used in clinical microbiological were used, which include application of selective diagnostic media, morpho-cultural and biochemical trials. A special attention was paid to identification of virulence and pathogenicity factors, such as proteolytic, hemolytic and saccharolytic activities.

It was found that the isolates Citrobacter koseri SCAID URN1-2019, Citrobacter freundii SCAID PHRX1-2019, Escherichia coli SCAID URN1-2019 and Pseudomonas aeruginosa spp. SCAID PHRX1-2019 demonstrate an increased virulent potential, particularly in their ability to form biofilms. Contrary, the clinical isolate Streptococcus pneumonia SCAID PHRX1-2019 showed a moderate ability to form microbial biofilms.

The selected clinical isolates showed resistance to many anti-bacterial drugs. Particularly, Citrobacter freundii SCAID PHRX1-2019 and Citrobacter koseri SCAID URN1 were resistant to oxacillin (a second line reserved antibiotic), azithromycin, erythromycin, streptomycin and clindamycin. Citrobacter freundii SCAID PHRX12019 is additionally resistant to carbenicillin and ampicillin. Moreover, it shows an intermediate susceptibility to amoxicillin, gentamicin, ceftriaxone, ciprofloxacin and cefepim.

E. coli SCAID URN1-2019 is as another example of multi-resistant germs. It is resistant to $\square$-lactams oxacillin, amoxicillin and ampicillin; macrolide antibiotic erythromycin, and to clindamycin (a semisynthetic antibiotic of the group lincosamides). However, this strain was susceptible to cephalosporins cefazolin, ceftriaxone and cefepim; aminoglycosides gentamicin and tobramycin; capbapenems meropenem and imipenem; and the macrolide antibiotic azithromycin.

Streptococcus pneumonia SCAID PHRX1-2019 is characterized by resistance to amikacin, cefepime, streptomycin and oxacillin. It was found that the resistance to oxacillin is mediated by the presence of the gene mecA, which encodes resistance to $\beta$ lactam antibiotics. The isolate also shows an intermediate sensitivity to azithromycin, ceftriaxone, carbenicillin and ampicillin. 
The antibiotic susceptibility profile of the Pseudomonas aeruginosa SCAID PHRX1-2019 is characterized by a broad range resistance to four classes of antibiotics: penicillins, cephalosporins, macrolides, and lincosamides. This strain was susceptible to aminoglycosides, carbapenems and fluoroquinolones.

Whole genome sequencing of the clinical isolates was performed. The obtained complete genome sequences were deposited at NCBI under the access numbers CP052060 for the Streptococcus pneumoniae SCAID_PHRX1-2019, CP052057 for the Escherichia coli SCAID URN1-2019, CP052059 for the Citrobacter koseri SCAID URN1-2019, and CP052058 for the isolate Citrobacter freundii SCAID PHRX1-2019.

The search for genetic determinants of drug resistance in the obtained genome sequences revealed multiple genes associated with the resistance to $\beta$-lactams, macrolides, aminoglycosides, lincosamides, cephalosporins and fluoroquinolones.

The obtained experimental results and genetic markers of microorganisms associated with nosocomial infections will facilitate further studies on improvement of techniques of monitoring and prediction of nosocomial outbreaks and will contribute to an improvement of treatment protocols of prevention and prophylaxis of emerging and spread of antibiotic resistance.

\section{CONCLUSION}

Clinical samples of bacteria associated with nosocomial infections were collected from phthisiological hospitals in Almaty. Morpho-cultural and physiologicalbiochemical characterization of the isolates was performed using the standard microbiological approaches, which include a detailed phenotypic description of cell and colony morphology, characteristic pigment production and the ability to grow on diagnostic media. The conducted studies showed that the isolates associated with nosocomial infections are characterized by an increased ability to form biofilms that significantly complicates the therapy and prevention of these outbreaks. Antibiotic susceptibility profiles were determined for all the isolates using an array of 18 most common antibiotics. Clinical isolates were characterized by varying degrees of susceptibility to antimicrobial drugs. Surprisingly, some strains were resistant to azithromycin, which is considered as a reserve drug. This fact raises a concern about the circulation and the spread in hospitals of microorganisms resistant to the latest generation of antibiotics.

Four isolates were selected for genome-wide sequencing. After sequencing and assembly, whole genome sequences of the strains Citrobacter koseri SCAID URN12019, Citrobacter freundii SCAID PHRX1-2019, E. coli SCAID URN1-2019 and Streptococcus pneumoniae SCAID PHRX1-2019 were obtained and deposited at NCBI. The search for genetic determinants of drug resistance in whole genome sequences of the strains was performed. Identified antibiotic resistance genes may explain the phenomenon of the resistance of Citrobacter freundii SCAID PHRX1-2019 and Citrobacter koseri SCAID URN1-2019 to the reserve antibiotics such as oxacillin, azithromycin, erythromycin, streptomycin and clindamycin.

The obtained experimental data whole genome sequences of the microorganisms causing nosocomial infections will further contribute to improving the monitoring of nosocomial outbreaks development of new protocols of prevention of the spread of antibiotic resistance and the treatment of patients suffering from drug resistant pathogens.

\section{Acknowledgements}


Collection of isolates from hospitals was carried out by employees of the Department of clinical trials of JSC "Scientific center for anti-infectious drugs", according to the agreement \# 16, from 26.02.2018.

The research was funded by grant 0.0776 of the program "Study on the reversion of antibiotic resistance in pathogenic microorganisms" provided by the Industrial development and industrial safety committee of the Ministry of industry and infrastructural development of the Republic of Kazakhstan.

\section{REFERENCES}

1. Chen Y., He Y., Zhang W., Huang Y., Fu J., Fu F., Zhou Y. Pathogenic characteristics of nosocomial infections in patients with cerebrovascular diseases and characteristics and treatment of pathogenic bacteria in different seasons // Journal of Infection and Public Health. - 2019. - Vol. 13, No 3. - P. 1-6. 31831394, http:// 10.1016/j.jiph.2019.11.010.

2. Edwardson S., Cairns Ch. Nosocomial infections in the ICU // Anaesthesia \& Intensive Care Medicine. - 2019. - Vol. 20, No 1. - P. 14-18. http://doi.org/10.1016/j.mpaic.2018.11.004.

3. Rosenthal V.D., Bat-Erdene I., Gupta D., Belkebir S., Rajhans P., Zand F. et al. International Nosocomial Infection Control Consortium (INICC) report, data summary of 45 countries for 2012-2017: Device-associated module // American Journal of Infection Control. - 2020. - Vol. 48, No 4. - P. 423-432. http://doi.org/10.1016/j.ajic.2019.08.023.

4. The burden of health care-associated infection worldwide / WHO. - 2016. Available at: http://www.who.int/gpsc/country_work/burden_hcai/en/ (accessed 07 May 2020).

5. Types of healthcare-associated infections. Healthcare-associated infections (HAIs) / CDC. - 2014. Available at: https://www.premiersafetyinstitute.org/safetytopics-az/healthcare-associated infections-hais/hai/ (accessed 04 May 2020).

6. HAI data and statistics. Healthcare-associated infections / CDC. - 2018. Available at: https://www.cdc.gov/hai/data/portal/index.html (accessed 04 May 2020).

7. Jenkins D.R. Nosocomial infections and infection control // Medicine. - 2017. - Vol. 45, No 10. - P. 629-633. http://doi.org/10.1016/j.mpmed.2017.07.005.

8. Urinary tract infection (catheter-associated urinary tract infection [CAUTI] and non-catheter associated urinary tract infection [UTI]) and other urinary system infection [USI]) events / CDC. - 2016. -22 p.

9. Guidelines on Core Components of Infection Prevention and Control Programmes at the National and Health Care Facility Level / WHO. $-2015 .-59$ p.

10. Khan H., Baig F., Mehboob R. Nosocomial infections: Epidemiology, prevention, control and surveillance // Asian Pacific Journal of Tropical Biomedicine. 2017. - Vol. 7, No 5. - P. 478-482. https://doi.org/10.1016/j.apjtb.2017.01.019.

11. High levels of antibiotic resistance found worldwide, new data shows / WHO. - 2018. Available at: https://www.who.int/mediacentre/news/releases/2018/antibioticresistance-found/en/ (accessed 14 May 2020).

12. Satlin MJ, Walsh TJ. Multidrug-resistant Enterobacteriaceae, Pseudomonas aeruginosa and vancomycin-resistant Enterococcus: Three major threats to hematopoietic stem cell transplant recipients // Transpl Infect Dis. - 2017. - Vol. 19, No 6. -29 p. doi: 10.1111/tid.12762.

13. ВОЗ публикует список бактерий, для борьбы с которыми срочно требуется создание новых антибиотиков / WHO. - 2018. Available at: 
https://www.who.int/ru/news-room/27-02-2017-who-publishes-list-of-bacteria-forwhich-new-antibiotics-are-urgently-needed (accessed 13 May 2020).

14. Manual for the Laboratory Identification and Antimicrobial Susceptibility Testing of Bacterial Pathogens of Public Health Importance in the Developing World // (WHO/CDS/CSR/RMD/2003.6). Available https://apps.who.int/iris/handle/10665/68554 (accessed 13 May 2020).

15. Baron E.J., York M., Ferraro M., Rex J., Body B., Forbes B., Poole F., Sahm D., Tenover F., Turnidge J., Wilson M. M35-A2 Abbreviation Identification of Bacteria and Yeasts Approved Guideline-Second Edition / CLSI. - 2008. - 13 p. $432 \mathrm{c}$.

16. Хоулт Дж. Определитель бактерий Берджи. В 2 т. Т.1 - М.: Мир, 1997. -

17. MUK 4.2.2886-11. Идентификация микроорганизмов и определение чувствительности их к антибиотикам с применением автоматизированной системы для биохимического анализа / Государственное санитарноэпидемиологическое нормирование РФ. - М, 2011. - 41 с.

18. Performance Standards for Antimicrobial Disc Susceptibility Test // CLSI. 2010. - Vol. 30, No 1. - 76 p.

19. Toole G., Kaplan H.B., Kotler R. Biofilm formation as Microbial Development // Annual Review of Microbiology. - 2000. - Vol. 54. - P. 49-79. 11018124, http://10.1146/annurev.micro.54.1.49.

20 Bankevich A., Nurk S., Antipov D. et al A New Genome Assembly Algorithm and Its Applications to Single-Cell Sequencing // Journal of Computational Biology. 2012. - Vol. 19, No5. - P. 455-477. doi: 10.1089/cmb.2012.0021.

21. Okonechnikov K., Golosova O., Fursov M. The UGENE team. Unipro UGENE: a unified bioinformatics toolkit // Bioinformatics. - 2012. - Vol.28, No. 8. P. 1166-1167. http://10.1093/bioinformatics/bts091.

22. Darling A.C.E., Mau B., Blattner F.R., Perna N.T. Mauve: multiple alignment of conserved genomic sequence with rearrangements. Genome research. - 2004. Vol. 14, No7. - P. 1394-1403. 10.1101/gr.2289704.

23. Alcock B.P., Raphenya A.R., Lau T. Y. et al. CARD 2020: Antibiotic Resistome Surveillance With the Comprehensive Antibiotic Resistance Database // Nucleic Acids. - 2020. - Vol. 8, No 48. - P. 517-525. doi: 10.1093/nar/gkz935.

24. Korotetskiy I.S., Jumagaziyeva A.B., Reva O.N., Kuznetsova T.V., Shvidko S.V., Iskakbayeva Z.A., Myrzabayeva A.H., Ilin A.I. Isolation and characterization isolates of nosocomial infections // Bulletin of National Academy of Sciences of the Republic of Kazakhstan. - 2019. - Vol. 5, No. 381. - P. 199-209. https://doi.org/10.32014/2019.2518-1467.140.

\section{REFERENCES}

1. Chen Y., He Y., Zhang W., Huang Y., Fu J., Fu F., Zhou Y. Pathogenic characteristics of nosocomial infections in patients with cerebrovascular diseases and characteristics and treatment of pathogenic bacteria in different seasons. Journal of Infection and Public Health, 2019, vol. 13, no. 3, pp. 1-6. 31831394, http://doi: 10.1016/j.jiph.2019.11.010

2. Edwardson S., Cairns Ch. Nosocomial infections in the ICU. Anaesthesia \& Intensive Care Medicine, 2019, vol. 20, no. 1, pp. 14-18. http://doi.org/10.1016/j.mpaic.2018.11.004

3. Rosenthal V.D., Bat-Erdene I., Gupta D., Belkebir S., Rajhans P., Zand F. et al. International Nosocomial Infection Control Consortium (INICC) report, data summary of 45 countries for 2012-2017: Device-associated module. American Journal 
of Infection Control, 2020, vol. 48, no. 4, pp. 423-432. http://doi.org/10.1016/j.ajic.2019.08.023

4. The burden of health care-associated infection worldwide. WHO (2016). Available at: http://www.who.int/gpsc/country_work/burden_hcai/en/ (accessed 07 May 2020).

5. Types of healthcare-associated infections. Healthcare-associated infections (HAIs). CDC (2014). Available at: https://www.premiersafetyinstitute.org/safety-topicsaz/healthcare-associated infections-hais/hai/ (accessed 04 May 2020).

6. HAI data and statistics. Healthcare-associated infections. CDC, 2018. Available at: https://www.cdc.gov/hai/data/portal/index.html (Accessed 04 May , 2020).

7. Jenkins D.R. Nosocomial infections and infection control. Medicine, 2017, vol. 45, no. 10, pp. 629-633. http://doi.org/10.1016/j.mpmed.2017.07.005

8. Urinary tract infection (catheter-associated urinary tract infection [CAUTI] and non-catheter associated urinary tract infection [UTI]) and other urinary system infection [USI]) events. CDC, 2016. 22 p.

9. WHO. Guidelines on Core Components of Infection Prevention and Control Programmes at the National and Health Care Facility Level. 2015. 59 p.

10. Khan H., Baig F., Mehboob R. Nosocomial infections: Epidemiology, prevention, control and surveillance. Asian Pacific Journal of Tropical Biomedicine, 2017, vol. 7, no. 5, pp. 478-482. https://doi.org/10.1016/j.apjtb.2017.01.019

11. High levels of antibiotic resistance found worldwide, new data shows. WHO, 2018. Available at: https://www.who.int/mediacentre/news/releases/2018/antibioticresistance-found/en/ (accessed 14 May 2020).

12. Satlin MJ, Walsh TJ. Multidrug-resistant Enterobacteriaceae, Pseudomonas aeruginosa and vancomycin-resistant Enterococcus: Three major threats to hematopoietic stem cell transplant recipients. Transpl Infect Dis, 2017, vol. 19, no. 6, 29 p. doi: $10.1111 /$ tid.12762.

13. VOZ publikuet spisok bakterij, dlya borby s kotorymi srochno trebuetsya sozdanie novyh antibiotikov [WHO publishes a list of bacteria that urgently needs new antibiotics to fight]. WHO, 2018. Available at: https://www.who.int/ru/news-room/2702-2017-who-publishes-list-of-bacteria-for-which-new-antibiotics-are-urgently-needed (accessed 13 May 2020).

14. Manual for the Laboratory Identification and Antimicrobial Susceptibility Testing of Bacterial Pathogens of Public Health Importance in the Developing World. (WHO/CDS/CSR/RMD/2003.6). Available at: https://apps.who.int/iris/handle/10665/68554 (accessed 13 May 2020).

15. Baron E.J., York M., Ferraro M., Rex J., Body B., Forbes B., Poole F., Sahm D., Tenover F., Turnidge J., Wilson M. M35-A2 Abbreviation Identification of Bacteria and Yeasts Approved Guideline-Second Edition. CLSI, 2008. 13 p.

16. Hoult Dzh. Opredelitel bakterij Berdzhi. V 2 t. T.1. [Burgee Bacterial Identifier. In 2 vol. Vol.1]. Mir Publ, 1997. 432 p.

17. MUK 4.2.2886-11. Identifikaciya mikroorganizmov $i$ opredelenie chuvstvitelnosti ih $k$ antibiotikam $s$ primeneniem avtomatizirovannoj sistemy dlya biohimicheskogo analiza [MUK 4.2.2886-11 Identification of microorganisms and determination of their sensitivity to antibiotics using an automated system for biochemical analysis]. State sanitary and epidemiological regulation of the Russian Federation. Moscow, 2011. 41 p.

18. Performance Standards for Antimicrobial Disc Susceptibility Test. CLSI, 2010, vol. 30, no 1, 76 p. 
19. Toole G., Kaplan H.B., Kotler R. Biofilm formation as Microbial Development. Annual Review of Microbiology, 2000, vol. 54, pp. 49-79. 11018124, http://10.1146/annurev.micro.54.1.49.

20 Bankevich A., Nurk S., Antipov D. et al A New Genome Assembly Algorithm and Its Applications to Single-Cell Sequencing. Journal of Computational Biology, 2012, vol. 19, no 5, pp. 455-477. doi: 10.1089/cmb.2012.0021.

21. Okonechnikov K., Golosova O., Fursov M. The UGENE team. Unipro UGENE: a unified bioinformatics toolkit. Bioinformatics, 2012, vol. 28, no. 8, pp. 1166-1167. http:// 10.1093/bioinformatics/bts091

22. Darling A.C.E., Mau B., Blattner F.R., Perna N.T. Mauve: multiple alignment of conserved genomic sequence with rearrangements. Genome research. 2004, vol. 14, no 7, pp. 1394-1403. 10.1101/gr.2289704

23. Alcock B.P., Raphenya A.R., Lau T. Y. et al. CARD 2020: Antibiotic Resistome Surveillance With the Comprehensive Antibiotic Resistance Database. Nucleic Acids, 2020, vol. 8, no 48, pp. 517-525. doi: 10.1093/nar/gkz935.

24. Korotetskiy I.S., Jumagaziyeva A.B., Reva O.N., Kuznetsova T.V., Shvidko S.V., Iskakbayeva Z.A., Myrzabayeva A.H., Ilin A.I. Isolation and characterization isolates of nosocomial infections. Bulletin of National Academy of Sciences of the Republic of Kazakhstan, 2019, vol. 5, no. 381, pp. 199-209. https://doi.org/10.32014/2019.2518-1467.140. 

ИЗОЛЯТТАРДЫН ФЕНОТИПТІК ЖӘНЕ ГЕНОТИПТІК

СИПАТТАМАСЫ

Коротецкий И.С. ${ }^{1}$, Джумагазиева А.Б. ${ }^{1}$, Шилов С.В. ${ }^{1}$, Кузнецова Т.В. ${ }^{1}$, Искакбаева Ж.А. ${ }^{1}$, Мырзабаева А.Н. ${ }^{1}$, Коротецкая Н.В. ${ }^{1}$, Ильин А.И. ${ }^{1}$, Рева O.H. ${ }^{2}$

${ }^{1}$ «Инфекииява қ̧арсы препараттар вылыми ортальвы» АҚ, Қазақсстан, 050060, Алматы қ̧аласы, Әл-Фараби данувыльы, 75 А-үй

${ }^{2}$ Биоинформатика және компьютерлік биология; ОАР, Притория, Притория Университеті, Биохимия, генетика және микробиология бөлімі; laeda1@mail.ru

\section{ТYЙІН}

Зерттеудің мақсаты антибиотикке сезімталдықтың қалпына келу құбылысының әмбебаптығын зерттеу үшін штамм банкін сипаттау және құру мақсатында ауруханаішілік инфекциялардың клиникалық изоляттарын сәйкестендіру болып табылады.

Алматы қ. және Алматы облысының фтизиатр саласының стационарынан нозокоминалдық инфекциялардың клиникалық изоляттарын жинақтау жүргізілді. Клиникалық изоляттардың микробқа қарсы препараттарға морфо-мәдени, тинктикалық, физиологиялық және биохимиялық қасиеттері мен сезімталдық саласы зерттелді.Олардын генетикалық сәйкестендірілуі жүргізілді.Бактериядан ДНҚ бөлінуі PureLink Genomic DNA Kits жиынтығымен өткізілді. ДНҚ кітапханасы IonXpress Plus Fragment Library kit жиынтығын пайдалану арқылы фрагменттеу жолымен алынды. Алынған ДНҚ кітапханасын штрих-кодтау IonXpress Barcode жиынтығының көмегімен жүзеге асырылды.

Алынған штрих-кодтталған ДНК кітапханасын жүктеу IonTorrent PGM аппараттарына секвенирлеу арқылы Ion Chip 318 іске асырылды. Геномды жинақтау Ugene бағдарламалық пакеті көмегімен жүргізілді.

Сандық зерттеулердің нәтижелері One-Way ANOVA бip жақты дисперсияны талдаудың әдісі бойынша өңделді, содан кейін Graf Pad Prism 6 қолданбалы бағдарламалардың пакетін қолдана отырып талдау жүргізілді. Алынған нәтижелерді кестелік және кестелік бейнелеу үшін Graf Pad Prism 6 бағдарламасы қолданылды.

Жүргізілген зерттеулер нәтижесінде 5 клиникалық изоляттар бөлінді. Төрт изоляттың толық геномды нуклеотидтік салдар анықталды Citrobacter koseri SCAID URN1-2019, Citrobacter freundii SCAID PHRX1-2019, Escherichia coli SCAID URN1-2019 және Streptococcus pneumoniae SCAID PHRX1-2019. Нәтижелер NCBI халықаралық деректер базасында сақталды.

Негізгі сөздер: ауруханаішілік инфекциялар, изоляттар, ДНК, секвенирлеу, Citrobacter koseri, Citrobacter freundii, Escherichia coli, Streptococcu spneumoniae.

\footnotetext{
ФЕНОТИПИЧЕСКАЯ И ГЕНОТИПИЧЕСКАЯ ХАРАКТЕРИСТИКА КЛИНИЧЕСКИХ ИЗОЛЯТОВ, ВЫЗЫВАЮЩИХ ВНУТРИБОЛЬНИЧНЫЕ ИНФЕКЦИИ
} 
Коротецкий И.С. ${ }^{1}$, Джумагазиева А.Б. ${ }^{1}$, Шилов С.В. ${ }^{1}$, Кузнецова Т.В. ${ }^{1}$, Искакбаева Ж.А. ${ }^{1}$, Мырзабаева А.Н. ${ }^{1}$, Коротецкая Н.В. ${ }^{1}$, Ильин А.И. ${ }^{1}$, Рева O.H. ${ }^{2}$

${ }^{1}$ АО «Научный иенттр противоинфекционных препаратов», пр. аль-Фараби, 75 А, Алматы, 050060, Казахстан

${ }^{2}$ Центр биоинформатики и компьютерной биологии; Отдел биохимии, генетики и микробиологии; Университет Притории, Притория, ЮАР

laeda1@mail.ru

\section{АБСТРАКТ}

Целью исследования являлась идентификация клинических изолятов внутрибольничных инфекций, с целью характеристики и создания банка штаммов для изучения универсальности феномена реверсии антибиотикочувствительности.

Проведен сбор клинических изолятов нозокомиальных инфекций из стационаров фтизиатрического профиля г. Алматы и Алматинской области. Изучены морфо-культуральные, тинкториальные, физиологобиохимические свойства и профиль чувствительности к антимикробным препаратам клинических изолятов. Проведена их генетическая идентификация. Выделение ДНК из бактерий произведено набором PureLink Genomic DNA Kits. ДНК библиотека была получена путем фрагментирования с использованием набора IonXpress Plus Fragment Library kit. Баркодирование полученной ДНК библиотеки проводили при помощи набора IonXpress Barcode. Загрузку полученной баркодированной ДНК библиотеки осуществляли на Ion 318 Chip с последующим секвенированием на аппарате IonTorrent PGM. Сборка генома производилась с помощью пакета программ Ugene.

Результаты проведенных количественных исследований подвергались обработке при помощи метода однофакторного дисперсионного анализа OneWay ANOVA c последующим анализом с помощью пакета прикладных программ Graph Pad Prism 6. Для табличного и графического изображения полученных результатов использовалась программа Graph Pad Prism 6.

В результате проведенных исследований выделено 5 клинических изолятов. Определена полногеномная нуклеотидная последовательность четырех изолятов - Citrobacter koseri SCAID URN1-2019, Citrobacter freundii SCAID PHRX1-2019, Escherichia coli SCAID URN1-2019 и Streptococcus pneumoniae SCAID PHRX1-2019. Результаты депонированы в базе международной данных NCBI.

Ключевые слова: внутрибольничные инфекции, изоляты, ДНК, секвенирование, Citrobacter koseri, Citrobacter freundii, Escherichia coli, Streptococcu spneumoniae. 
